\title{
Hubungan Status Gizi dengan Tingkat Produktivitas Pekerja Wanita di PT. Idec Abadi Wood Industries Tarakan
}

\author{
Risaldi $^{1}$, Ratih Wirapuspita ${ }^{1}$ dan Iriyani $\mathbf{K}^{\mathbf{1}^{*}}$ \\ ${ }^{1}$ Fakultas Kesehatan Masyarakat Universitas Mulawarman \\ E-mail: iriyanikamaruddin@gmail.com*
}

\begin{abstract}
Factors that affect worker producktivity is the intake level of nutrient of worker who can be seen from their nutritional status. The need for workers nutrition must be in accordance with the job. A worker with a good nutritional state will have a better working capacity and endurance, on the other hand a worker with a poor nutritional state will accelerate exhaustion and this can disrupt productivity. This study aims to know the correlation of nutritional status that consists of body mass index, energi intake, protein intake, and intake of iron to the productivity of female workers in PT. Idec Abadi Wood Industries. This study uses cross sectional study design. The sample in this study was a female worker at the wholesale totaling 50 people, by measured the body mass index (BMI) and recall 24 hours. Data analysis technique used is multiple linier regression. Result from the study showed an association between nutrional status (BMI) and productivity $(0,001<0,05)$, energy intake with productivity $(0.008<0,05)$, intake of iron with productivity $(0.045<0.05)$. And there was no significant association between protein intake and productivity $(0,243<0,05)$. Companies were advised to make a special program for the monitoring process and the adequacy of nutrient intake of workers. The company needs to add medical personel especially in the field of nutrition. Dissemination of information through sosialization, posters or leflets on the pattern of balanced nutrition for workers
\end{abstract}

Keywords : Productivity, Nutritional Status, women

\section{Pendahuluan}

Produktivitas adalah perbandingan antara keluaran (output) dan masukan (input). Faktor yang mempengaruhi produktivitas kerja adalah beban kerja, beban tambahan akibat lingkungan kerja, kapasitas kerja dan status gizi. Salah satu faktor yang mempengaruhi produktivitas kerja adalah tingkat asupan gizi pekerja yang dilihat dari status gizi mereka. Santoso (2004) menyatakan bahwa pekerjaan memerlukan

Anemia merupakan masalah kesehatan masyarakat terbesar di dunia terutama bagi kelompok wanita usia reproduksi (WUS). Anemia pada WUS dapat menimbulkan kelelahan, badan lemah, penurunan kapasitas/kemampuan atau produktivitas kerja. Bagi ibu hamil, anemia berperan pada peningkatan prevalensi kematian dan kesakitan ibu, dan bagi bayi dapat meningkatkan risiko kesakitan dan kematian bayi (Syafiq,dkk.,2007). tenaga yang sumbernya dari makanan yang mana kebutuhan akan gizi tenaga kerja harus sesuai dengan pekerjaannya. Seorang tenaga kerja dengan keadaan gizi yang baik akan memiliki kapasitas kerja dan ketahanan tubuh yang lebih baik, begitu pula sebaliknya pada tenaga kerja dengan keadaan gizi yang buruk dan dengan beban kerja yang berat akan mengganggu kerja dan mempercepat kelelahan (Budiyono, 2008).

Anemia umumnya terjadi diseluruh dunia, terutama di negara berkembang (developing countries) pada kelompok sosia ekonomi rendah. Pada kelompok dewasa, anemia terjadi pada wanita usia reproduksi, terutama wanita hamil dan wanita menyusui karena mereka banyak mengalami defisiensi Fe. Secara keseluruhan, anemia terjadi pada $45 \%$ wanita di negara berkembang dan $13 \%$ di negara maju (developing countries) (Syafiq,dkk.,2007). 
Tujuan dari penelitian ini adalah untuk mengetahui hubungan status gizi, asupan kalori, asupan protein dan asupan zat besi dengan tingkat produktivitas pekerja di PT. Idec Abadi Wood Industries, Tarakan.

\section{Metode penelitian}

Jenis penelitian ini menggunakan metode deskriptif analitik dengan rancangan penelitian cross sectional study. Sampel dalam penelitian ini adalah para pekerja wanita pada bagian borongan di PT. Idec Abadi Wood Industries, yang diambil secara random (acak) menggunakan simple random sampling dengan jumlah 50 orang.
Teknik pengumpulan data dengan cara melakukan pengukuran antropometri dan pengisian recall 24 jam. Teknik analisis data menggunakan uji regresi linier berganda dengan $\alpha=0.05$

\section{Hasil dan pembahasan}

\subsection{Hasil Penelitian}

Hasil penelitian ini terdiri dari gambaran asupan zat gizi, produktivitas dan usia pekerja wanita Di PT. Idec Abadi Wood Industries, Tarakan. Berikut merupakan gambaran asupan zat gizi, produktivitas dan usia pekerja wanita :

Tabel 1. Gambaran Asupan Zat Gizi, Produktivitas dan Usia Pekerja Wanita Di PT. Idec Abadi Wood Industries, Tarakan

\begin{tabular}{clcccc}
\hline No & \multicolumn{1}{c}{ Variabel } & Minimal & Maksimal & Mean \pm SD & Total \\
\hline 1 & Produktivitas & 164,5 & 292,5 & $214,29 \pm 29,24$ & 10714,5 \\
2 & Status Gizi (IMT) & 15 & 39 & $25,05 \pm 7,10$ & 1252,5 \\
3 & Tingkat Konsumsi Energi & 34,15 & 174,48 & $114,52 \pm 42,39$ & 5726,20 \\
4 & Tingkat Konsumsi Protein & 40,48 & 282,8 & $166,9 \pm 64,24$ & 8341,34 \\
5 & Tingkat Konsumsi Besi & 32,39 & 181,5 & $155,01 \pm 41,47$ & 5750,78 \\
6 & Usia Pekerja & 19 & 60 & $36,44 \pm 8,62$ & 1822 \\
& Total Pekerja & & & 50 & \\
\end{tabular}

Berdasarkan tabel di atas usia pekerja wanita di PT. Idec Abadi Wood Industries ratarata 36,44 dengan standar deviasi 8,62. Variabel status gizi mempunyai nilai minimal IMT 15 sampai dengan nilai maksimal 39, dan rata rata IMT 25,05. Variabel tingkat konsumsi energi mempunyai nilai minimal $34,15 \%$ sampai dengan nilai maksimal $174,48 \%$. Rata rata dari konsumsi energi pekerja di PT. Idec Abadi Wood Industries sebesar 114,52\%. Variabel tingkat konsumsi protein mempunyai nilai rata - rata sebesar $166,9 \%$. Sedangkan standar deviasi sebesar 64,24. Dan variabel tingkat konsumsi zat besi mempunyai nilai rata - rata $115,01 \%$, dengan standar deviasa 41,47. Sedangkan variabel produktivitas pekerja mempunyai nilai rata - rata 214,29 , dengan standar deviasi 29,24.

\section{Frekuensi Status Gizi Pekerja Wanita di PT. Idec Abadi Wood Industries}

Berikut merupakan frekuensi dari status gizi para pekerja wanita di perusahaan tersebut.

Tabel 2. Frekuensi Status Gizi Pekerja Wanita di PT. Idec Abadi Wood Industries

\begin{tabular}{clcc}
\hline No & \multicolumn{1}{c}{ Status Gizi } & Frequensi & Persen $(\boldsymbol{\%})$ \\
\hline 1 & Gizi Baik & 23 & 46 \\
2 & Gizi Kurang & 9 & 18 \\
3 & Gizi Lebih & 18 & 36 \\
& Total & 50 & 100 \\
\hline
\end{tabular}


Berdasarkan table 2 dapat diketahui sebaran frekuensi dari status gizi pekerja wanita di PT. Idec Abadi Wood Industries terdapat $46 \%$ pekerja dengan status gizi baik, $18 \%$ pekerja dengan status gizi kurang dan $36 \%$ gizi lebih.

\section{Analisis Regresi Linier Berganda Pada Tingkat Produktivitas Pekerja Wanita di PT. Idec Abadi Wood Industries, Tarakan}

Berikut merupakan koefisen korelasi dan determinasi dari variabel produktivitas terhadapat variabel status gizi, asupan kalori, asupan protein dan asupan zat besi.

Tabel 3. Koefisien Korelasi dan Determinasi

\begin{tabular}{llrrrr}
\hline Model & $\mathrm{R}$ & R Square & $\begin{array}{c}\text { Adjusted R } \\
\text { Square }\end{array}$ & $\begin{array}{c}\text { Std. Error of the } \\
\text { Estimate }\end{array}$ & Durbin-Watson \\
\hline 1 &, $886^{\mathrm{a}}$ &, 786 &, 767 & 14,12543 & 2,018 \\
\hline
\end{tabular}

Pengaruh yang dijelaskan oleh variabel tersebut sangat berarti dan memperlihatkan hubungan yang kuat dan bersifat positif dengan nilai koefisien korelasi (R) sebesar 0,886. Dengan demikian hasil data dapat disimpulkan bahwa secara bersama-sama variabel status gizi $\left(\chi_{1}\right)$, tingkat konsumsi energi $\left(\chi_{2}\right)$, tingkat konsumsi protein $\left(\chi_{3}\right)$ dan tingkat konsumsi zat besi $\left(\chi_{4}\right)$ memiliki hubungan yang kuat terhadap tingkat produktivitas pekerja wanita di PT. Idec Abadi Wood Industries

Berdasarkan hasil diatas bahwa $\mathrm{R}$ Square $\left(\mathrm{R}^{2}\right)$ disebut juga koefisien determinasi dimana nilainya adalah sebesar 0,786 yang artinya menunjukkan variabel status gizi $\left(\chi_{1}\right)$, tingkat konsumsi energi $\left(\chi_{2}\right)$, tingkat konsumsi protein $\left(\chi_{3}\right)$ dan tingkat konsumsi zat besi $\left(\chi_{4}\right)$ dapat menjelaskan tingkat produktivitas pekerja wanita $(\gamma)$ sebesar $78,6 \%$ pada variabel tingkat produktivitas pekerja wanita di PT. Idec Abadi Wood Industries disebabkan oleh variasi yang terjadi status gizi, tingkat konsumsi energi, tingkat konsumsi protein dan tingkat konsumsi zat besi serta sisanya sebesar $21,4 \%$ tidak dapat diterangkan dalam model ini karena dipengaruhi oleh faktor lain diluar penelitian.

\section{Pengujian Hipotesis Pertama}

Berikut merupakan hasil pengujian hipotesis pertama dengan menggunakan uji simultan (Uji $F$ )

Tabel 4. Uji Simultan (uji F)

\begin{tabular}{lllllll}
\hline Model & & Sum of Squares & Df & Mean Square & F & Sig. \\
\hline \multirow{4}{*}{1} & Regression & 32919,794 & 4 & 8229,948 & 41,247 &, $000^{\mathrm{b}}$ \\
& Residual & 8978,751 & 45 & 199,528 & & \\
& Total & 41898,545 & 49 & & & \\
\hline
\end{tabular}

Berdasarkan hasil analisis diperoleh nilai signifikan $(0,000)<\alpha(0.05)$ dan nilai $\mathrm{F}_{\text {hitung }}=$ $41,247>\mathrm{F}_{\text {tabel }}=2,58$, maka berhubungan signifikan dan diputuskan menolak $\mathrm{H}_{0}$ dan menerima $\mathrm{H}_{1}$. Jadi, dengan demikian hipotesis pertama yang menyatakan secara simultan (bersama-sama) antara status gizi $\left(\chi_{1}\right)$, tingkat konsumsi energi $\left(\chi_{2}\right)$, tingkat konsumsi protein $\left(\chi_{3}\right)$ dan tingkat konsumsi zat besi $\left(\chi_{4}\right)$ berhubungan signifikan terhadap variabel tingkat produktivitas pekerja wanita di PT. Idec Abadi Wood Industri.

\section{Pengujian Hipotesis Pertama}

Berikut merupakan hasil pengujian hipotesis pertama dengan menggunakan uji parsial (Uji T). 
Tabel 5. Uji Parsial (Uji T)

\begin{tabular}{|c|c|c|c|c|c|}
\hline \multirow{2}{*}{ Model } & \multicolumn{2}{|c|}{$\begin{array}{l}\text { Unstandardized } \\
\text { Coefficients }\end{array}$} & \multirow{2}{*}{$\begin{array}{c}\text { Standardized } \\
\text { Ceofficients } \\
\text { Beta }\end{array}$} & \multirow{2}{*}{$\mathbf{T}$} & \multirow{2}{*}{ Sig } \\
\hline & B & Std. Error & & & \\
\hline (Constants) & 132,073 & 8,299 & & 16,094 & ,000 \\
\hline Status Gizi & 1,318 & ,318 & ,320 & 3,462 & ,001 \\
\hline $\begin{array}{l}\text { Tingkat Konsumsi } \\
\text { Energi }\end{array}$ &, 307 & ,095 & ,445 & 3,222 & ,002 \\
\hline $\begin{array}{l}\text { Tingkat Konsumsi } \\
\text { Protein }\end{array}$ &,- 041 & 035 &,- 091 & $-1,182$ & ,243 \\
\hline $\begin{array}{l}\text { Tingkat Konsumsi Zat } \\
\text { Besi }\end{array}$ &, 182 & ,088 & ,258 & 2,063 & ,045 \\
\hline
\end{tabular}

Berdasarkan hasil analisis diperoleh nilai Sig $(0,000)<\alpha(0.05)$ dan nilai $\mathrm{t}_{\text {hitung }}=$ $16,049>\mathrm{t}_{\text {tabel }}=1,679$ maka secara parsial berhubungan signifikan dan diputuskan menolak $\mathrm{H}_{0}$ dan menerima $\mathrm{H}_{1}$. Jadi, ada hubungan signifikan nilai konstanta status gizi $\left(\chi_{1}\right)$, tingkat konsumsi energi $\left(\chi_{2}\right)$, tingkat konsumsi protein $\left(\chi_{3}\right)$ dan tingkat konsumsi zat besi $\left(\chi_{4}\right)$ dengan variabel tingkat produktivitas pekerja wanita di PT. Idec Abadi Wood Industries.

\subsection{Pembahasan}

Berdasarkan hasil analisis diperoleh nilai Sig $(0,001)<\alpha(0.05)$ dan nilai $\mathrm{t}_{\text {hitung }}=$ $3,462>\mathrm{t}_{\text {tabel }}=1,679$ maka secara parsial berhubungan signifikan dan diputuskan menolak $\mathrm{H}_{0}$ dan menerima $\mathrm{H}_{1}$. Jadi, ada hubungan signifikan status gizi dengan tingkat produktivitas pekerja wanita di PT. Idec Abadi Wood Industries. Dari hasil pengujian dan analisis tersebut dapat diinterpretasikan bahwa indikator-indikator variabel status gizi mempunyai hubungan dengan tingkat produktivitas pekerja wanita.

Status gizi merupakan keadaan tubuh sebagai akibat kombinasi makanan dan penggunaan zat gizi (Almatsier, 2010). Status gizi yang normal untuk wanita berdasarkan IMT adalah 18,5-25,5. Kesehatan tenaga kerja dan produktivitas kerja erat bertalian dengan status gizi (Budiono, dkk., 2008). Manusia yang sehat dan mendapatkan makanan yang cukup, baik kulitas maupun kuantitasnya, akan memiliki kesanggupan yang maksimal dalam menjalani hidupnya. Kemampuan maksimal ini disebut "kapasitas orang dewasa". Jadi untuk memperoleh kapasitas orang dewasa yang maksimal, manusia harus memperoleh makanan yang cukup sehingga memperoleh semua zat gizi yang diperlukan untuk pertumbuhan, perbaikan dan pemeliharaan jaringan tubuh dan terlaksananya fungsi faal normal dalam tubuh, di samping memperoleh energi yang cukup untuk memungkinkan bekerja secara maksimal. Bagi tenaga kerja kekurangan akan zat gizi akan mengakibatkan gangguan kesehatan. Gangguan tersebut akan mempengaruhi kapasitas kerja secara keseluruhan menjadi berkurang dan keadaan itu tentu saja akan menurunkan produktivitas kerja (Moehji, 2009).

Gizi kerja adalah zat yang dibutuhkan oleh tenaga kerja untuk memenuhi kebutuhan sesuai dengan pekerjaanya agar tingkat kesehatan dan produktivitas kerjanya tercapai setinggi-tingginya (Santoso, 2010). Tubuh memerlukan zat-zat dari makanan untuk pemeliharaan tubuh. Perbaikan dari kerusakan sel-sel maupun jaringan tubuh. Zat-zat makanan ini diperlukan untuk pekerjaan dan meningkat berbanding lurus dengan beratnya pekerjaan. Pekerjaan memerlukan tenaga yang sumbernya adalah makanan, dalam kaitan dengan gizi kerja, nutrisi yang diperlukan oleh tenaga kerja tidak berbeda dengan yang dibutuhkan oleh orang lain dan dalam kegiatan lain (Anies, 2007). Bekerja keras tanpa diimbangi dengan makanan yang bergizi yang dimakan setiap hari 
maka dalam waktu dekat akan menderita kekurangan tenaga, lemas dan tidak dapat bergairah dalam melakukan pekerjaanya, tentu saja yang bersangkutan tidak dapat diharapkan adanya produktivitas yang dikehendaki (Kartasapoetra \& Marsetyo, 2007).

Gizi kerja merupakan salah satu syarat mencapai derajat kesehatan yang optimal, khususnya bagi masyarakat pekerja. Kesehatan itu sendiri mencakup dua aspek yaitu: aspek kesejahteraan dan aspek pengembangan sumber daya manusia. Demikian pula gizi di satu pihak mempunyai aspek kesehatan dan dilain pihak mempunyai aspek mencerdaskan kehidupan bangsa serta menunjang produktivitas, oleh karena itu perbaikan dan peningkatan gizi mempunyai peran yang sangat penting dalam upaya menyehatkan, mencerdaskan serta meningkatkan produktivitas kerja (Anies, 2007).

Nugroho (2007) dalam penelitiannya dengan judul "Hubungan Antara Status Gizi dengan Produktivitas Tenaga Kerja Wanita di PT. Java Tobacco Gembongan Kartasura" menyatakan bahwa ada hubungan antara status gizi dengan produktivitas. Sama halnya dengan penelitian dari Adiyatna (2013) dengan judul "Hubungan Antara Status Gizi dan Motivasi Kerja Dengan Produktivitas Tenaga Kerja Wanita Bagian Giling Rokok di PT. Notojorono Kudus" yang membuktikan bahwa ada hubungan antara status gizi dengan tingkat prokduktivitas kerja.

Sejalan dengan penelitian yang di lakukan oleh Nugroho (2014), penelitian yang di lakukan di PT. Idec Abadi Wood Industries Tarakan juga menunjukkan adanya hubungan status gizi dengan produktivitas pekerja. Karena status gizi pekerja sangat penting dalam faktor produksi. Hal ini ditegaskan oleh pendapat dari Santoso (2006) yang mengatakan bahwa, gizi kerja adalah zat yang dibutuhkan oleh tenaga kerja untuk memenuhi kebutuhan sesuai dengan pekerjaanya agar tingkat kesehatan dan produktivitas kerjanya tercapai setinggitingginya.
Berdasarkan hasil analisis diperoleh nilai $\operatorname{Sig}(0,008)<\alpha(0.05)$ dan nilai $t_{\text {hitung }}=3,222>$ $\mathrm{t}_{\text {tabel }}=1,679$ maka secara parsial berhubungan signifikan dan diputuskan menolak $\mathrm{H}_{0}$ dan menerima $\mathrm{H}_{1}$. Jadi, ada hubungan signifikan variabel tingkat konsumsi energi terhadap variabel tingkat produktivitas pekerja wanita di PT. Idec Abadi Wood Industries. Dari hasil pengujian dan analisis tersebut dapat diinterpretasikan bahwa indikator-indikator variabel tingkat konsumsi energi mempunyai hubungan terhadap variabel tingkat produktivitas pekerja wanita.

Salah satu cara untuk meningkatkan produktivitas kerja dengan menjaga pola konsumsi pangan. Apabila tubuh kekurangan zat gizi, khususnya energi dan protein, pada tahap awal akan meyebabkan rasa lapar dan dalam jangka waktu tertentu berat badan akan menurun yang disertai dengan menurunnya produktivitas kerja dan apabila tubuh kelebihan zat gizi maka pada tahap awal menyebabkan kegemukan dan selanjutnya mempengaruhi gerakan menjadi tidak gesit dan lamban, mempunyai risiko penyakit degeneratif yang dapat memicu menurunnya produktivitas kerja (Supriasa, 2009).

Wignjosoebroto (2008), perbaikan dalam produktivitas semata-mata tidak harus melalui penambahan kecepatan bekerja, yaitu dimana jam kerja sebagai faktor masukan yang diperkecil atau dipersingkat nilai waktunya dengan cara meninggikan performans kerja manusianya. Kerja yang terlalu cepat ada kalanya justru akan banyak menimbulkan kesalahan atau cacat dari keluaran yang dihasilkan. Konsumsi pangan yang kurang dan berlebihan akan sangat berpengaruh dengan tingkat konsumsi energi yang dimiliki setiap pekerja sortasi lansia, kekurangan konsumsi pangan akan meyebabkan rasa lapar pada tahap awal dan dalam jangka waktu tertentu berat badan akan menurun yang disertai dengan menurunya produktivitas kerja, dan seiring dengan kekurangan konsumsi energi, kelebihan konsumsi energi juga akan menyebabkan 
kelebihan energi yang dapat memicu kegemukan pada pekerja dan selanjutnya memengaruhi gerakan menjadi lamban dan tidak gesit, kelambanan atau tidak gesit dalam gerakan dapat menurunkan produktivitas kerja.

Bagi tenaga kerja, gizi dengan kalori yang memadai menjadi syarat utama yang menentukan tingkat produktivitas kerja, antara kesehatan, status gizi dan produktivitas kerja terdapat korelasi yang sangat nyata. Tenaga kerja dengan status gizi dibawah normal, meskipun persentasenya tidak besar tetapi perlu mendapat perhatian, hal ini karena konsumsi energi yang kurang memadai akan menyebabkan kebutuhan energi untuk bekerja akan diambil dari energi cadangan yang terdapat dalam sel. Apabila hal ini terjadi akibatnya tenaga kerja yang bersangkutan tidak dapat melakukan pekerjaan secara baik dan produktivitas kerjanya akan menurun bahkan dapat mencapai target rendah, untuk tenaga kerja dengan status gizi gemuk maka orang tersebut kurang gesit dan lamban dalam bekerja. Sedangkan orang yang mempunyai berat badan normal akan lebih lincah dalam bekerja (Susanti, 2012).

Penelitian di PT. Idec Abadi Wood Industries sejalan dengan penelitian yang dilakukan oleh Harianti (2012) dengan judul "Hubungan Tingkat Konsumsi Energi dengan Produktivitas Pekerja Sortasi Lansia di Kebuh Klambir V PTPN II" menyatakan bahwa ada hubungan asupan energi atau asupan makanan dengan produktivitas pekerja. Sama halnya dengan Handayani (2013) dalam penelitiannya yang berjudul "Hubungan Tingkat Konsumsi dan Penggunaan Cetakan Terhadap Produktivitas Kerja“" membuktikan bahwa ada hubungan antara asupan energi atau asupan makanan dengan tingkat produktivitas pekerja. Karena salah satu cara untuk meningkatkan produktivitas pekerja dengan menjaga pola konsumsi pangan. Apabila tubuh kekurangan zat gizi, khususnya energi dan protein, pada tahap awal akan meyebabkan rasa lapar dan dalam jangka waktu tertentu berat badan akan menurun yang disertai dengan menurunnya produktivitas kerja dan apabila tubuh kelebihan zat gizi maka pada tahap awal menyebabkan kegemukan dan selanjutnya mempengaruhi gerakan menjadi tidak gesit dan lamban.

Dalam penelitian yang di lakukan di PT. Idec Abadi Wood Industries, berdasarkan hasil analisis diperoleh nilai Sig $(0,243)>\alpha(0.05)$ dan nilai $\mathrm{t}_{\text {hitung }}=1,182<\mathrm{t}_{\text {tabel }}=1,679$ maka secara parsial berhubungan signifikan dan diputuskan menerima $\mathrm{H}_{0}$ menolak $\mathrm{H}_{1}$. Jadi, tidak ada hubungan yang signifikan variabel tingkat konsumsi protein terhadap variabel tingkat produktivitas pekerja wanita di PT. Idec Abadi Wood Industries. Dari hasil pengujian dan analisis tersebut dapat diinterpretasikan bahwa indikator-indikator variabel tingkat konsumsi protein tidak mempunyai hubungan yang signifikan dengan variabel tingkat produktivitas pekerja wanita.

Protein merupakan suatu zat makanan yang sangat penting bagi tubuh, karena zat ini selain berfungsi sebagai bahan bakar dalam tubuh juga berfungsi sebagai zat pembangun dan pengatur (Kertasapoetra, 2007). Gizi pada pekerja mempunyai peran penting, baik bagi kesejahteraan maupun dalam rangkat meningkatkan disiplin dan produktivitas. Oleh karen itu pekerja perlu mendapatkan asupan protein yang cukup yang sesuai dengan jenis atau beban pekerjaan yang dilakukannya. Kekurangan protein pada makanan yang dikonsumsi tenaga kerja sehari - hari akan membawa akibat buruk terhadap tubuh, seperti : pertahanan tubug terhadap penyakit menjadi menurun, kemampuan fisik berkurang, berat bada menurun, badan menjadi kurus, kurang bersemangat, bereaksi lamban dan apatis. Dalam keadaan demikian itu tidak bisa diharapkan tercapainya efesiensi dan produktivitas pekerja yang optimal (Aziiza, 2008)

Handayani (2013) dalam penelitiannya dengan judul "Hubungan Tingkat Konsumsi dan Penggunaan Cetakan Terhadap Produktivitas Kerja“ membuktikan bahwa ada 
hubungan antara asupan protein dengan tingkat produktivitas pekerja. Namun dalam penelitian yang di lakukan di PT. Idec Abadi Wood Industries menyatakan tidak ada pengaruh yang signifikan konsumsi protein terhadap tingkat produktivitas pekerja wanita di PT. Idec Abadi Wood Industries. Protein selain akan digunakan bagi pembangunan struktur tubuh juga akan disimpan untuk digunakan dalam keadaan darurat, sehingga pertumbuhan atau kehidupan dapat terus terjamin dengan wajar, akan tetapi dalam keadaan tidak diterimanya makanan yang tidak bergizi secara terus menerus, dengan sendirinya akan terjadi gejala-gejala kekurangan protein diantaranya adalah pertumbuhan kurang, daya tahan tubuh menurun, rentan terhadap penyakit dan daya kerja merosot (Kertasapoetra, 2007).

Berdasarkan hasil analisis diperoleh nilai Sig $(0,045)<\alpha(0.05)$ dan nilai $t_{\text {hitung }}=2,063>$ $\mathrm{t}_{\text {tabel }}=1,679$ maka secara parsial berhubungan signifikan dan diputuskan menerima $\mathrm{H}_{0}$ menolak $\mathrm{H}_{1}$. Jadi, ada hubungan yang signifikan variabel tingkat konsumsi zat besi terhadap variabel tingkat produktivitas pekerja wanita di PT. Idec Abadi Wood Industries. Dari hasil pengujian dan analisis tersebut dapat diinterpretasikan bahwa indikator-indikator variabel tingkat konsumsi zat besi mempunyai hubungan yang signifikan dengan variabel tingkat produktivitas pekerja wanita.

Faktor utama yang menjadi penyebab terjadinya anemia gizi besi adalah kurangnya konsumsi zat besi yang berasal dari makanan, atau rendahnya absorpsi zat besi yang ada dalam makanan. Ketersediaan zat besi dari makanan yang tidak cukup mengakibatkan tubuh mengalami anemia gizi besi. Di negaranegara sedang berkembang dengan tingkat ekonomi yang relatif rendah, umumnya zat besi yang berasal dari sumber pangan nabati (non heme iron) yang mempunyai nilai absorbsi yang lebih rendah dibandingkan dengan absorpsi zat besi yang berasal dari pangan hewani (heme iron). Penyerapan zat besi non heme sangat dipengaruhi oleh faktor penghambat maupun faktor pendukung, sedang besi heme tidak. Asam askorbat (Vitamin C) adalah salah satu faktor pendorong absorpsi zat besi di samping itu keberadaan tanin dalam teh dapat menghambat penyerapan zat besi (Anies, 2007)

Penelitian yang dilakukan di PT. Idec Abadi Wood Industries menyatakan ada hubungan antara asupan zat besi (Fe) dengan produktivitas pekerja. Hal ini juga dibuktikan oleh penelitian yang dilakukan oleh Nasution dan Lubis (2004) dengan judul "Hubungan Konsumsi Zat Besi Dan Status Gizi Dengan Produktivitas Kerja Wanita Pencetakan Batu Bata Di Kecamatan Pagar Merbau Kabupaten Deli Serdang" menunjukkan bahwa ada hubungan antara asupan zat besi dengan tingkat produktivitas pekerja. Karena pekerja wanita merupakan kelompok yang rentan terhadap anemia gizi, hal ini disebabkan oleh kurangnya zat besi dalam makanan dan pekerjaan yang berat serta secara alamiah wanita setiap bulan mengalami haid. Hasil penelitian Husaini menunjukkan bahwa produktivitas pekerja wanita penderita anemia gizi menurun 10 $20 \%$. Oleh karena itu perlu diadakan upaya penanggulangannya, agar kualitas sumber daya manusia dapat dimanfaatkan secara maksimal (Anies, 2007).

\section{Kesimpulan dan saran}

Berdasarkan hasil penelitian terdapat hubungan signifikan status gizi dengan tingkat produktivitas yang memiliki nilai Sig $(0,001)<$ $\alpha(0.05)$, ada hubungan asupan kalori dengan tingkat produktivitas yang memiliki nilai Sig $(0,008)<\alpha(0.05)$. ada hubungan asupan protein dengan tingkat produktivitat yang memiliki nilai Sig $(0,243)>\alpha(0.05)$ dan ada hubungan asupan zat besi dengan tingkat produktivitas yang memiliki nilai Sig $(0,045)<$ $\alpha(0.05)$ di PT. Idec Abadi Wood Industries Tarakan.

\section{REKOMENDASI}

Pembuatan program khusus untuk pemantauan kecukupan asupan gizi pekerja. 
Penambahan tenaga medis terutama di bidang gizi. Program pemberian makanan tambahan kembali dijalakan. Memberikan keringanan karyawan wanita yang sedang sakit, menstruasi

\section{DAFTAR PUSTAKA}

Adiyatna, FC, 2013, Hubungan Antara Status Gizi Dan Motivasi Kerja Dengan Produktivitas Tenaga Kerja Wanita Bagian Giling Rokok Di PT. Nojorono Kudus. Jurnal. Universitas Negeri Semarang.

Aini, S.N. 2012. Faktor-Faktor Yang Berhubungan Dengan Kejadian Gizi Lebih Pada Remaja Di Perkotaan. Unnes Journal of Public Health. http://journal.unnes.ac.id/sju/inde x.php/ujph

Almatsier, S. 2010. Prinsip Dasar Ilmu Gizi. Jakarta: Gramedia Pustaka Utama

Anies, 2007, Penyakit Akibat Kerja, Jakarta: Kelompok Gramedia.

Aziiza, F, 2008, Analisis Aktivitas Fisik, Konsumsi Pangan, Dan Status Gizi Dengan Produktivitas Kerja Pekerja Wanita Di Industri Konveksi. Situs : http://repository.ipb.ac.id/bitstrea $\mathrm{m} / \mathrm{handle} / 123456789 / 1866 / \mathrm{A08faz}$ .$p d f$ ? sequence $=5$. Akses : Juli 2 , 2012

Budiyono, AMS. 2008, Bunga Rampai Hiperkes dan Kesehatan Kerja, Semarang: Badan Penerbit Undip.

Handayani, T. 2013. Hubungan Umur, Masa Kerja, dan Status Gizi Dengan dan hamil. Serta penyebaran informasi mengenai pola gizi seimbang bagi pekerja.

Produktivitas Kerja Perajin Wanita Di Bagian Percetakan Awal Genteng Di Desa Demakan. Jurnal. Universitas Sumatera Utara

Harianti NN., Kalsum., Mahyuni EL. 2012. Hubungan Tingkat Konsumsi Energi dengan Produktivitas Pekerja Sortasi Lansia di Kebuh Klambir V PTPN II. Jurnal. Universitas Sumatera Utara.

Kartasapoetra G \& Marsetyo H. 2007. Ilmu Gizi: Korelasi Gizi, Kesehatan dan Produktivitas Kerja. Jakarta: Rineka Cipta.

Nugroho, V.A, 2014. Hubungan Antara Status Gizi dengan Produktivitas Tenaga Kerja Wanita di PT. Java Tobacco Gembongan Kartasura. Jurnal. Universitas Negeri Semarang.

Santoso, G.,2010. Manajemen Keselamatan dan Kesehatan Kerja. Jakarta. Penerbit: Prestasi Pustaka.

Supariasa IDN., Bakri B., Fajar I. 2009. Penilaian Status Gizi. Jakarta: EGC.

Susanti, Wiwik, 2012. Hubungan Antara Status Gizi Dengan Produktivitas Tenaga Kerja Wanita di Perusahaan Rokok Pamor Kudus, Jurnal. Universitas Negeri Sebelas Maret.

Wingjosoebroto, S. 2008, Ergonomi, Studi Gerak Dan Waktu Teknik Analisis Untuk Peningkatan Produktivitas Kerja, Prima Printing, Surabaya. 